\title{
DOSES AND FORMS OF APPLICATION OF PHOSPHORUS IN VERNALIZED GARLIC
}

\author{
Leonardo Theodoro Büll1*; Mirian Cristina Gomes Costa²; Aline Novello³; Dirceu Maximino \\ Fernandes ${ }^{1}$; Roberto Lyra Villas Bôas ${ }^{1}$ \\ ${ }^{1}$ UNESP/FCA - Depto. de Recursos Naturais/Ciência do Solo, C.P. 237 - 18603-970 - Botucatu, SP - Brasil. \\ ${ }^{2}$ USP/ESALQ - Programa de Pós-Graduação em Solos e Nutrição de Plantas, C.P. 9 - 13418-900 - Piracicaba, SP - \\ Brasil. \\ ${ }^{3}$ R. José Ferraz de Carvalho, 605 apto. 102 Centro - 13400-550 - Piracicaba, SP - Brasil. \\ *Corresponding author <bull@fca.unesp.br>
}

\begin{abstract}
Because of low P mobility in the soil, the effect of its position in relation to the root is of great practical significance, especially in soils with extreme P deficiency. Experiments with vegetables under this approach are not frequent. This work studies the influence of the position of phosphate fertilizer on nutrient absorption and on the production of vernalized garlic (Allium sativum L.) bulbs. Two experiments were carried out in pots (16 L) containing samples of a Typic Quartzipsamment and of a Typic Hapludox in a factorial scheme with four $\mathrm{P}$ doses $\left(50,100,200\right.$, and $400 \mathrm{mg} \mathrm{P} \mathrm{dm}^{-3}$ ) and five positions relative to the incorporation (I) or furrow application (S), where $\mathrm{L}_{1}=100 \% \mathrm{I}, \mathrm{L}_{2}=75 \% \mathrm{I}$ and $25 \% \mathrm{~S}, \mathrm{~L}_{3}=50 \% \mathrm{I}$ and $50 \% \mathrm{~S}, \mathrm{~L}_{4}$ $=25 \% \mathrm{I}$ and $75 \% \mathrm{~S}$, and $\mathrm{L}_{5}=100 \% \mathrm{~S}$. Doses of fertilizer and forms of application influenced contents of phosphorus extracted by resin and from plant leaves, in both soils. Bulb yield increased with increasing $\mathrm{P}$ doses, and was influenced by the fertilizer's position only in the clayey soil.

Key words: Typic Quartzipsamment, Typic Hapludox, garlic, phosphorus position, phosphate fertilizer
\end{abstract}

\section{DOSES E MODOS DE APLICAÇÃO DE FÓSFORO EM CULTIVO DE ALHO VERNALIZADO}

\begin{abstract}
RESUMO: Devido à baixa mobilidade do fósforo no solo, o estudo do efeito de sua localização em relação ao sistema radicular tem grande significado prático, principalmente em solos com deficiência extrema de fósforo. Experimentos com hortaliças dentro dessa abordagem têm sido pouco freqüentes. O presente trabalho estuda o efeito de doses e da localização do fertilizante fosfatado sobre o estado nutricional e a produção de bulbos de alho vernalizado (Allium sativum L.), bem como sobre atributos químicos do solo. Instalaram-se dois experimentos em vasos $\left(16 \mathrm{dm}^{3}\right.$ ) com amostras de um Neossolo Quartzarênico Distrófico e de um Latossolo Vermelho Distroférrico, em esquema fatorial com quatro doses de fósforo (50, 100, 200 e $400 \mathrm{mg} \mathrm{P} \mathrm{dm}{ }^{-3}$ ) e cinco localizações em relação à incorporação (I) ou à aplicação no sulco (S), sendo $\mathrm{L}_{1}=100 \% \mathrm{I}, \mathrm{L}_{2}=75 \% \mathrm{I}$ e $25 \% \mathrm{~S}, \mathrm{~L}_{3}=50 \% \mathrm{I}$ e $50 \% \mathrm{~S}, \mathrm{~L}_{4}=25 \% \mathrm{I}$ e $75 \% \mathrm{~S}$ e $\mathrm{L}_{5}=100 \% \mathrm{~S}$. As doses e as formas de aplicação do fósforo influenciaram os teores de fósforo extraído por resina e na folha das plantas em ambos os solos. A produção de bulbos aumentou com as doses de fósforo e foi influenciada pela localização do fertilizante fosfatado apenas no solo argiloso.

Palavras-chave: Neossolo Quartzarênico, Latossolo Vermelho, Allium sativum (L.), localização de fósforo, adubação fosfatada
\end{abstract}

\section{INTRODUCTION}

Applications of phosphorus for garlic (Allium sativum L.) cropping in Brazilian soils are usually done at high rates, mostly because of the fixation of a large part of the soluble phosphate fertilizers. The problem worsened by the fact that fertilizer applications are done for the entire area, followed by incorporation into the soil at a depth of 20 to $30 \mathrm{~cm}$, considerably increasing the contact surface between the nutrient and the soil, favoring adsorption and, consequently, decreasing the nutrient's availability for the crop.

Because the proportion of added phosphorus that is adsorbed by the soil decreases with the applied amount, two options can be adopted to increase phosphorus concentration in the soil solution: increasing the dose for the same volume, or reducing the volume of fertilized soil for the same amount added. Phosphorus efficiency can be increased by mixing it with soil portions so that its absorption is optimized. However, application of the fertilizer to a restricted region of the soil could result in greater root growth at that site, in relation to the rest of the soil volume. This could be insufficient to meet the plant's nutritional demand and/or cause a reduction in water content at that region, decreasing phosphorus diffusion and absorption (Klepker \& Anghinoni, 1995).

Given the low mobility of phosphorus in the soil, studying the effect of its location relative to the root sys- 
tem on plant's behavior has great practical significance, especially in soils with extreme phosphorus deficiency (Novais et al., 1991), in which high productivities, especially in the first cropping year, will depend on corrective phosphate fertilization, in addition to localized fertilization at the planting furrow. One question that must be addressed is the determination of the maximum content of available phosphorus in a soil for which fertilizer application exclusively in the planting furrow, does not allow productivity limitations because of phosphorus deficiency (Novais et al., 1985).

Papers involving the study of phosphate fertilizer positions have received attention in Brazil, especially in extensive crops (Anghinoni, 1992; Model \& Anghinoni, 1992; Nacif et al., 1996; Silva et al., 1993, and Klepker \& Anghinoni, 1995). However, experiments with vegetables within this approach are much less frequent. Boaretto et al. (1982), studying P sources and forms of application in the soil for onion crops, verified that the application of phosphate fertilizers in the planting furrow is the most recommended method. Fontes (1987) also observed an increase in the efficiency of utilization of phosphorus by tomato plants with the localized application of phosphate fertilizer, in relation to broadcast application and incorporation in the entire area.

According to the results obtained by Fontes \& Fontes (1992), it is possible to provide adequate growth and phosphorus absorption by tomato plants with the application of only $0.6 \mathrm{~g} \mathrm{~m}^{-1} \mathrm{P}$ as soluble phosphates on the tomato seeds. Magalhães et al. (1986) observed that the amount of soluble phosphate required for obtaining the maximum yield in mustard could be reduced from 2,000 $\mathrm{kg} \mathrm{ha}^{-1}$ to $600 \mathrm{~kg} \mathrm{ha}^{-1}$ with the localized application in the planting forrow, as a replacement for mixing the fertilizer in the entire area.

Considering what has been discussed, a study was conducted to evaluate responses to phosphorus doses and forms of application by vernalized garlic, cv "Caçador São Marcos”.

\section{MATERIAL AND METHODS}

The study consisted of two experiments, carried out in green house under semi-controlled conditions in Botucatu/SP ( $22^{\circ} 51^{\prime \prime} \mathrm{S}, 48^{\circ} 26^{\prime} \mathrm{W}$; altitude $\left.786 \mathrm{~m}\right)$, in 15$\mathrm{dm}^{-3}$ asbestos cement pots. Surface samples (up to $25 \mathrm{~cm}$ ) from two low natural fertility soils were used: a Typic Quartzipsamment (TQ) and a Typic Hapludox (TH), (Table 1). Treatments for each soil were set up in a $4 \times 5$ factorial scheme, with four phosphorus doses and five phosphorus fertilizer locations, arranged as a completely randomized design $(n=3)$.

The phosphorus doses tested were: 50, 100, 200, and $400 \mathrm{mg} \mathrm{P} \mathrm{dm}^{-3}$ soil, corresponding to $229,458,916$, and $1,832 \mathrm{~kg} \mathrm{ha}^{-1} \mathrm{P}_{2} \mathrm{O}_{5}$. The nutrient source was triple
Table 1 - Chemical analysis and textural class results for the studied soils.

\begin{tabular}{lcc}
\hline Attribute & $\mathrm{TQ}^{1}$ & $\mathrm{TH}^{2}$ \\
\hline $\mathrm{pH}\left(\mathrm{CaCl}_{2} 0.01 \mathrm{~mol} \mathrm{~L}^{-1}\right)$ & 4.2 & 4.0 \\
Organic matter $\left(\mathrm{g} \mathrm{dm}^{-3}\right)$ & 9 & 36 \\
P-resin $\left(\mathrm{mg} \mathrm{dm}^{-3}\right)$ & 4 & 4 \\
Remaining P $\left(\mathrm{mg} \mathrm{dm}^{-3}\right)$ & 53 & 6 \\
$\mathrm{H}+\mathrm{Al}\left(\mathrm{mmol}_{\mathrm{c}} \mathrm{dm}^{-3}\right)$ & 22 & 93 \\
$\mathrm{~K}\left(\mathrm{mmol}_{\mathrm{c}} \mathrm{dm}^{-3}\right)$ & 1.0 & 1.0 \\
$\mathrm{Ca}\left(\mathrm{mmol}_{\mathrm{c}} \mathrm{dm}^{-3}\right)$ & 6 & 5 \\
$\mathrm{Mg}\left(\mathrm{mmol}_{\mathrm{c}} \mathrm{dm}^{-3}\right)$ & 3 & 3 \\
Sum of bases $\left(\mathrm{mmol}_{\mathrm{c}} \mathrm{dm}^{-3}\right)$ & 10 & 9 \\
$\mathrm{CEC}\left(\mathrm{mmol}_{\mathrm{c}} \mathrm{dm}^{-3}\right)$ & 32 & 102 \\
$\mathrm{~V} \%$ & 30 & 9 \\
Textural class & Sandy & Clayey \\
\hline
\end{tabular}

${ }^{1} \mathrm{TQ}$ - Typic Quartzipsamment

${ }^{2} \mathrm{TH}$ - Typic Hapludox

superphosphate (powder), distributed and incorporated (I) into the soils, in combination with localized applications in two parallel furrows (S), $15 \mathrm{~cm}$ apart from each other at a $5 \mathrm{~cm}$ depth below the seed-bulblets, according to the following positions (L): $\mathrm{L}_{1}-100 \%$ of the $\mathrm{P}$ dose incorporated; $\mathrm{L}_{2}-75 \% \mathrm{I}$ and $25 \% \mathrm{~S} ; \mathrm{L}_{3}-50 \%$ I and $50 \% \mathrm{~S} ; \mathrm{L}_{4}-$ $25 \% \mathrm{I}$ and $75 \% \mathrm{~S} ; \mathrm{L}_{5}-100 \%$ of the $\mathrm{P}$ dose in the furrows.

After application of dolomitic lime (90\% TNP), to achieve $80 \%$ base saturation (Trani et al., 1996), soils were moistened to $50 \%$ of their maximum water retention capacity for an incubation period of 40 days. Triple superphosphate was then applied the amounts and positions corresponding to each treatment. This procedure was performed after the supplementary planting fertilization, identical for all treatments, and consisting of the application of potassium chloride, calculated to achieve $(\mathrm{Ca}+\mathrm{Mg}) / \mathrm{K}$ ratios close to 12 by applying $6.3 \mathrm{~g}$ potassium chloride to each pot (Büll et al., 1992). Micronutrients were applied in the form of fritted trace elements (FTE BR 9), at the rate of $1.2 \mathrm{~g}$ FTE BR-9 per pot, corresponding to $120 \mathrm{~kg} \mathrm{ha}^{-1}$ of the fertilizer. Organic fertilization was omitted to avoid discrimination problems at low phosphorus levels, as reported by Büll et al. (1998a). Nitrogen fertilization was performed in the form of two sidedressings, by applying $1.4 \mathrm{~g}$ ammonium nitrate per pot at 30 and 50 days after emergence (dae), corresponding to the dose of $50 \mathrm{~kg} \mathrm{ha}^{-1} \mathrm{~N}$ per application.

Next, garlic (Allium sativum L.) Caçador São Marcos cultivar was sown, using 3 to 4 -g seed bulblets vernalized at $4^{\circ} \mathrm{C}$ for 45 day. Six bulblets were sown per pot, spaced $8 \mathrm{~cm}$ between plants and $15 \mathrm{~cm}$ between rows. Pine needles were used as mulch.

Soil samples were collected 30 days after planting to determine resin-extracted phosphorus content and other routine analysis indices $\left(\mathrm{CaCl}_{2} \mathrm{pH}, \mathrm{H}+\mathrm{Al}, \mathrm{K}, \mathrm{Ca}\right.$, 
and Mg), following methodologies described by Raij \& Quaggio (1983). Two ordinary samples containing soil from the pot surface to its bottom were collected using stainless steel sampling tube from each pot, in the direction of the planting furrows. At the end of the experiment, soil samples were collected from between the cultivation rows, i.e., without comprising the planting furrows. Samples to be analyzed combined three replicates of each treatment.

At the time of bulblet differentiation (70 dae), leaf samples were collected for chemical analysis of N, P, K, $\mathrm{Ca}, \mathrm{Mg}, \mathrm{Fe}, \mathrm{Mn}, \mathrm{Cu}$, and $\mathrm{Zn}$, to evaluate plant nutritional state (Bataglia et al., 1983). Bulb yield was determined after a curing period of 30 days.

\section{RESULTS AND DISCUSSION}

Data on the chemical analysis of soils, relative to samples collected 30 dae, in the furrow, and at the end of the experiment, between rows, are presented in Table 2. The $\mathrm{pH}$ values are within the suitable levels for the crop, with slightly lower values in TH for the two highest phosphorus doses. Reduction of $\mathrm{pH}$ was observed as the phosphorus dose applied in the TQ soil increases, regardless of phosphate fertilizer form of application; in the $\mathrm{TH}$ soil this was observed only in the two treatments with an increased proportion of phosphorus applied in the planting furrow (data not shown). Cruz (1994) and Büll et al. (1998a; 1998b) obtained similar results and attributed it to the acidification caused by the application of triple superphosphate, especially at higher doses.

In both soils, phosphorus contents extracted by resin increased proportionally to the phosphate fertilizer doses. However, higher available phosphorus contents were observed as the proportion of phosphorus applied in the planting furrow increased, especially as a result of samplings involving soil from the surface to the bottom of the pot, in the vertical direction of the two planting furrows (data not shown). Model \& Anghinoni (1992) compared the variation in fertilized soil portions, from $100 \%$ for broadcast application and from 3 to $5 \%$ for planting furrow application, considerably increasing the contents of recovered phosphorus in the latter form of application, because of the localized concentration of fertilizer. For the same phosphorus form of application and dose, the P-resin values were apparently smaller in the clayey soil in relation to the sandy soil (Table 2), which is compatible with the phosphorus fixation capacity of each soil, estimated by the remaining $P$ values that were determined (Alvarez V. et al., s.d.) (Table 1). According to Alvarez V. (1996), the maximum soil phosphorus adsorption capacity can be estimated by determining Prm; these indices are negatively correlated. These results are in agreement with those observed by Büll et al. (1998a),

Table 2 - Mean chemical analysis results for two soils with phosphorus position and dose variations, in samplings performed at the planting furrows (30 dae) and between furrows (at harvest).

\begin{tabular}{|c|c|c|c|c|c|c|}
\hline \multirow{3}{*}{ Treatments } & \multicolumn{3}{|c|}{ TQ } & \multicolumn{3}{|c|}{$\mathrm{TH}$} \\
\hline & \multicolumn{2}{|c|}{ Furrow } & \multirow{2}{*}{$\begin{array}{c}\text { Between Furrows } \\
\text { P-resin }\end{array}$} & \multicolumn{2}{|c|}{ Furrow } & \multirow{2}{*}{$\begin{array}{c}\text { Between Furrows } \\
\text { P-resin }\end{array}$} \\
\hline & $\mathrm{pH} \mathrm{CaCl}{ }_{2}$ & P-resin & & $\mathrm{pH} \mathrm{CaCl}{ }_{2}$ & P-resin & \\
\hline Rates $\left(\mathrm{mg} \mathrm{dm}^{-3}\right)$ & \multicolumn{3}{|c|}{ - } & \multicolumn{3}{|c|}{ - } \\
\hline 50 & 5.9 & 126 & 27 & 5.9 & 87 & 13 \\
\hline 100 & 5.9 & 247 & 42 & 5.9 & 212 & 19 \\
\hline 200 & 5.5 & 437 & 69 & 5.8 & 496 & 46 \\
\hline 400 & 5.4 & 927 & 130 & 5.7 & 718 & 78 \\
\hline Regression & $\mathrm{L}^{*}$ & $\mathrm{~L}^{* *} ; \mathrm{Q}^{*}$ & $\mathrm{~L}^{* *} ; \mathrm{Q}^{*}$ & $\mathrm{~L}^{*}$ & $\mathrm{~L}^{*} ; \mathrm{Q}^{*}$ & $\mathrm{~L}^{*}$ \\
\hline \multicolumn{7}{|l|}{ Position } \\
\hline L1 & $5.8 \mathrm{a}$ & $207 d$ & 123 & 5.8 & 120 e & 66 \\
\hline L2 & $5.7 \mathrm{ab}$ & $306 \mathrm{c}$ & 93 & 5.8 & $239 \mathrm{~d}$ & 48 \\
\hline L3 & $5.8 \mathrm{ab}$ & $456 \mathrm{~b}$ & 62 & 5.8 & $413 \mathrm{c}$ & 41 \\
\hline L4 & $5.6 \mathrm{bc}$ & $570 \mathrm{a}$ & 42 & 5.9 & $510 \mathrm{~b}$ & 32 \\
\hline L5 & $5.4 \mathrm{c}$ & $608 \mathrm{a}$ & 14 & 5.8 & $609 a$ & 8 \\
\hline F Test & $* *$ & $* *$ & \# & ns & $* *$ & \# \\
\hline C.V.\% & 2.5 & 20.8 & $\#$ & 1.4 & 17.3 & $\#$ \\
\hline
\end{tabular}

TQ - Typic Quartzipsamment; TH - Typic Hapludox.

$\mathrm{L}$ - linear regression; Q - quadratic regression; $\mathrm{R}^{2}$ - coefficient of determination; ns - non-significant, **- significant at $1 \%$; *- significant at $5 \%$; lower case letters compare position means (Tukey $5 \%$ ).

L1 = 100\% of incorporated P dose; L2 = 75\% incorporated and 25\% in furrow; L3 = 50\% incorporated and 50\% in furrow; L4 = 25\% incorporated and $75 \%$ in furrow; L5 = 100\% in furrow.

\# - no analysis of variance was applied 
differing, however, from those reported by Büll et al. (1998b), who did not observe differences in P-resin contents for five soils with distinct textural classes, regardless of variations in clay contents and in remaining $\mathrm{P}$ values.

The phosphorus contents at the end of the experiment in samples collected without comprising the planting furrows, therefore involving soil portions with variations in P-resin levels because of fertilizer doses and incorporated proportion, were smaller than those at the planting furrow at 30 dae. A significant and positive correlation ( $r=0.99$ for $\mathrm{TQ}$, and $r=0.98$ for $\mathrm{TH}$ ) was observed between the increasing percentages of $\mathrm{P}$ incorporated in the entire area and resin $\mathrm{P}$ obtained in the evaluation at harvest time, between rows. Because sampling was performed at the end of the experiment, it showed a reduction in soil $\mathrm{P}$ contents because of extraction by plants. However, the fact that the sampling did not comprise the planting furrow must prevail.

The exchangeable potassium contents found are in accordance with applied amounts, and there were practically no variations between soils; the average contents were 6.5 and $6.4 \mathrm{mmol}_{\mathrm{c}} \mathrm{K} \mathrm{dm}^{-3}$, for TQ and TH respectively. With regard to calcium and magnesium levels, these were different between soils because of the amounts calculated to determine liming requirements; the average contents were 36 and $56 \mathrm{mmol}_{\mathrm{c}}$ of $\mathrm{Ca} \mathrm{dm}^{-3}$, and 10 and $28 \mathrm{mmol}_{\mathrm{c}}$ of $\mathrm{Mg} \mathrm{dm}^{-3}$, for TQ and TH, respectively. Increasingly higher calcium contents were observed as the phosphorus dose increased in both soils. The mean cal- cium contents, from the smallest to the highest phosphorus dose applied were 28, 30, 35, and $49 \mathrm{mmol} \mathrm{Ca} \mathrm{dm}^{-3}$ for TQ, with a significant linear regression fitting at $1 \%$ probability $\left(\mathrm{R}^{2}=0.99\right)$, and $46,50,58$, and $69 \mathrm{mmol}_{\mathrm{c}} \mathrm{Ca}$ $\mathrm{dm}^{-3}$ for $\mathrm{TH}$, with a significant linear regression fitting at $1 \%$ probability $\left(\mathrm{R}^{2}=0.98\right)$. These variations, also verified by Büll et al. (1998a), must be associated with the calcium supplied by the triple superphosphate, which presents $15 \% \mathrm{Ca}$ in its composition. Base saturation was quite near the previously calculated values, with mean values of $78 \%$ for TQ and $80 \%$ for $\mathrm{TH}$, reaching the desired levels in both soils, contradicting reports by Caires \& Rosolem (1993) and Büll et al. (1998a), who observed soil base saturation values lower than those calculated for the liming requirements.

The leaf phosphorus contents increased with applied dose in both soils (Table 3), with values for the sandy soil, on average, 37\% higher than those for the clayey soil, compatible with P-resin contents (Table 2), and especially with Prm values (Table 1), thus confirming the importance of knowing this index to evaluate phosphorus absorption by plants grown in soils with distinct granulometric characteristics (Alvarez V., 1996). Similar results were obtained by Büll et al. (1998a; 1998b). The form of application of phosphorus influenced the leaf concentration of this element in both soils; in the sandy soil, the highest value was obtained for the treatment with all the fertilizer applied in the form of incorporation, while in the clayey soil the highest value was

Table 3 - P, Mn, and Fe contents in the leaves and yield (g per 4 plants) of garlic plant bulbs submitted to different phosphorus positions and doses in two soils.

\begin{tabular}{|c|c|c|c|c|c|c|c|c|}
\hline \multirow{2}{*}{ Treatments } & \multicolumn{2}{|c|}{$\mathrm{P}$ contents } & \multicolumn{2}{|c|}{ Mn contents } & \multicolumn{2}{|c|}{ Fe contents } & \multicolumn{2}{|c|}{ Bulb Yield } \\
\hline & TQ & $\mathrm{TH}$ & TQ & $\mathrm{TH}$ & TQ & $\mathrm{TH}$ & TQ & $\mathrm{TH}$ \\
\hline Doses $\left(\mathrm{mg} \mathrm{dm}^{-3}\right)$ & \multicolumn{2}{|c|}{ - $\mathrm{g} \mathrm{kg}^{-1} \ldots$} & \multicolumn{2}{|c|}{-...- $\mathrm{mg} \mathrm{kg}^{-1} \ldots$} & \multicolumn{2}{|c|}{-...- mg kg ${ }^{-1}$} & \multicolumn{2}{|c|}{ g per 4 plants } \\
\hline 50 & 3.5 & 2.7 & 36 & 41 & 90 & 114 & 89 & 95 \\
\hline 100 & 3.7 & 2.9 & 37 & 47 & 77 & 117 & 94 & 103 \\
\hline 200 & 4.1 & 3.2 & 46 & 49 & 80 & 110 & 102 & 110 \\
\hline 400 & 4.6 & 3 & 80 & 49 & 79 & 107 & 100 & 100 \\
\hline Effects & $\mathrm{L}^{* *} ; \mathrm{Q}^{*}$ & $\mathrm{Q}^{*}$ & $\mathrm{~L}^{*} ; \mathrm{Q}^{*}$ & ns & ns & ns & $\mathrm{Q}^{*}$ & $\mathrm{Q}^{*}$ \\
\hline \multicolumn{9}{|l|}{ Position } \\
\hline L1 & $4.2 \mathrm{a}$ & $3 a b$ & $38 \mathrm{~b}$ & 47 & $97 \mathrm{a}$ & 114 & 95 & $96 \mathrm{ab}$ \\
\hline $\mathrm{L} 2$ & $4.0 \mathrm{ab}$ & $2.8 \mathrm{~b}$ & $39 \mathrm{~b}$ & 44 & $82 \mathrm{ab}$ & 101 & 95 & $102 \mathrm{ab}$ \\
\hline L3 & $3.9 \mathrm{~b}$ & $3.1 \mathrm{ab}$ & $51 \mathrm{~b}$ & 46 & $77 \mathrm{~b}$ & 128 & 93 & $109 \mathrm{a}$ \\
\hline L4 & $3.9 \mathrm{~b}$ & $3.5 \mathrm{a}$ & $51 \mathrm{~b}$ & 45 & $76 \mathrm{~b}$ & 103 & 96 & 109 a \\
\hline L5 & $3.9 \mathrm{~b}$ & $2.3 \mathrm{c}$ & $71 \mathrm{a}$ & 50 & $76 \mathrm{~b}$ & 113 & 101 & $94 \mathrm{~b}$ \\
\hline F Test & $*$ & $* *$ & $* *$ & ns & $* *$ & $\mathrm{~ns}$ & ns & $*$ \\
\hline C.V.\% & 7.5 & 14.9 & 29 & 16 & 16 & 32 & 16 & 11 \\
\hline
\end{tabular}

TQ - Typic Quartzipsamment; TH - Typic Hapludox.

L - linear regression; $\mathrm{Q}$ - quadratic regression; $\mathrm{R}^{2}$ - coefficient of determination; ns - non-significant;

**- significant at 1\%; *- significant at 5\%; lower case letters compare position means (Tukey 5\%).

L1 $=100 \%$ of incorporated P dose; L2 = 75\% incorporated and 25\% in furrow; L3 = 50\% incorporated and 50\% in furrow; L4 = 25\% incorporated and $75 \%$ in furrow; L5 $=100 \%$ in furrow. 
obtained for the treatment involving $75 \%$ of the dose in the planting furrow and 25\% incorporated to the soil.

The leaf iron concentration was only influenced in the sandy soil, and was lower in treatments with 50\% or more of the fertilizer in the furrow as compared with the totally incorporated fertilizer. Manganese concentration increased with phosphorus doses in the sandy soil; these results are identical to those obtained by Büll (1998a; 1998b), and were attributed by those authors to a greater release of the micronutrient in that soil because of the reduction in $\mathrm{pH}$ value as phosphorus doses increased (Table 2). Again, for TQ, application of all the phosphorus in the planting furrow provided leaf manganese contents clearly higher than in the other treatments.

With regard to the other macro and micronutrients analyzed (data not shown), the phosphorus doses and forms of application only influenced leaf magnesium contents. Mg contents decreased as phosphorus doses increased, corroborating with Büll et al. (1998a; 1998b), with values, from the smallest to the highest phosphorus doses, of 4.7; 4.3; 4.0; and $3.9 \mathrm{~g} \mathrm{Mg} \mathrm{kg}^{-1}$ for TQ, and 4.9; 4.9; 4.8; and $4.5 \mathrm{~g} \mathrm{Mg} \mathrm{kg}^{-1}$ for TH. The absence of treatment effects on leaf zinc contents (mean value of $15 \mathrm{mg}$ $\mathrm{kg}^{-1}$ for both soils) corroborates with Büll et al. (1998a; 1998b), who did not observe an antagonistic effect of phosphorus on the absorption of these micronutrient, which are common in soils that received high doses of phosphate fertilizers (Stukenholtz et al., 1966; Boawn \& Brown, 1968; Edwards \& Kamprath, 1974).

Bulb yield increased with phosphorus doses in both soils (Table 3). In papers also dealing with varying soil phosphorus levels, Büll et al. (1998a; 1998b) observed bulb yield increases proportional to the phosphorus doses in medium- and clayey-textured soils. The position of the phosphate fertilizer influenced bulb yield only in garlic plants grown in clayey soil. The greatest bulb yields were obtained when one half of the phosphate fertilizer was applied in the planting furrow and the other half was incorporated into the soil, and also in the treatment involving $75 \%$ of the dose in the furrow and $25 \%$ of the dose incorporated into the soil. Yields in these treatments were higher than that obtained with the whole application in the planting furrow.

Obtaining high productivities, especially in the first cropping year, in soils showing extreme phosphorus deficiency as those used in this work, depends upon corrective phosphorus applications, in addition to localized fertilization in the planting furrow; the variations presented here, especially for the soil with a higher clay content, are coherent with those resulting from corrective phosphate applications (Novais et al., 1991). Phosphate fertilizer position affects bulb yield only in clayey soil, and confirm the importance of discriminating different soil textures and therefore, their phosphorus fixation capacities, for phosphate fertilization management in veg- etables, where massive phosphate doses incorporated into the soil are commonly applied. Predicting the soil's phosphorus fixation capacity can be easily done in routine soil analysis laboratories, consisting in an important soil discrimination tool.

\section{ACKNOWLEDGEMENT}

To CNPq for financial support - Research Productivity and Research Initiation Scholarships.

\section{REFERENCES}

ALVAREZ V., V.H. Correlação e calibração de métodos de análise de solos. In: ALVAREZ V., V.H.; FONTES, L.E.F.; FONTES, M.P.F. (Ed.) O solo nos grandes domínios morfoclimáticos do Brasil e o desenvolvimento sustentado. Viçosa: SBCS, 1996. p.615-646.

ALVAREZ V., V.H.; DIAS, L.E.; OLIVEIRA, J.A. Determinação do fósforo remanescente (Prm). Viçosa: Universidade Federal de Viçosa, s.d. 11p.

ANGHINONI, I. Uso de fósforo pelo milho afetado pela fração de solo fertilizada com fosfato solúvel. Revista Brasileira de Ciência do Solo, v.16, p.349-353, 1992.

BATAGLIA, O.C.; FURLANI, A.M.C.; TEIXEIRA, J.P.F.; FURLANI, P.R.; GALLO, J.R. Métodos de análises química de plantas. Boletim Técnico do Instituto Agronômico, n.48, p.1-48, 1983.

BOARETTO, A.E.; SILVA, N.; BÜLL, L.T.; KIMOTO, T. Fontes de fósforo e métodos de aplicação no solo na cultura de cebola (Allium cepa L.) pelo sistema de bulbinho. Científica, v.10, p.241-245, 1982.

BOAWN, L.C.; BROWN, J.C. Further evidences for a P x Zn imbalances in plants. Soil Science Society of America Proceedings, v.32, p.94-97, 1968.

BÜLL, L.T. Efeitos das relações Ca:Mg:K na cultura do alho (Allium sativum, L.) cv. Roxo Pérola de Caçador. Botucatu: UNESP/FCA, 1992. 114p. (Tese - Livre-Docência).

BÜLL, L.T.; FORLI, F.; TECCHIO, M.A.; CORRÊA, J.C. Relações entre fósforo extraído por resina e respostas da cultura do alho vernalizado a adubação fosfatada em cinco solos com e sem adubação orgânica. Revista Brasileira de Ciência do Solo, v.22, p.459-470, 1998a.

BÜLL, L.T.; NOVELLO, A.; COSTA, M.C.G.; VILLAS BÔAS, R.L. Interação fósforo-zinco na cultura do alho vernalizado. In: REUNIÃO BRASILEIRA DE FERTILIDADE DO SOLO E NUTRIÇÃO DE PLANTAS, 23., Caxambu, 1998. Resumos. Lavras: SBCS, 1998b. p.135.

CAIRES, E.F.; ROSOLEM, C. Calagem em genótipos de amendoim. Revista Brasileira de Ciência do Solo, v.17, p.193-202, 1993.

CRUZ, L.A.A. Desenvolvimento inicial de mamoeiro relacionado à disponibilidade de fósforo no solo. Botucatu: UNESP/FCA, 1994. 96p. (Dissertação - Mestrado).

EDWARDS, J.H.; KAMPRATH, E.J. Zinc accumulation by corn seedlings as influenced by phosphorus, temperature and light intensity. Agronomy Journal, v.66, p.479-782, 1974.

FONTES, P.C.R. Distribuição de fósforo no solo afetando o desenvolvimento e absorção de fósforo pelo tomateiro. Pesquisa Agropecuária Brasileira, v.22, p.367-372, 1987.

FONTES, P.C.R.; FONTES, R.C. Absorção de fósforo e crescimento do tomateiro influenciado por fontes, níveis e posicionamento do fertilizante. Horticultura Brasileira, v.10, p.11-13, 1992.

KLEPKER, D.; ANGHINONI, I. Crescimento radicular e aéreo do milho em vasos em função do nível de fósforo no solo e da localização do adubo fosfatado. Revista Brasileira de Ciência do Solo, v.19, p.403408, 1995.

MAGALHÃES, J.R.; RODRIGUES, F.C.; FERREIRA ROSSI, P.E. Nova abordagem para recomendação de fósforo na cultura da mostarda. Horticultura Brasileira, v.4, p.13-16, 1986.

MODEL, N.S.; ANGHINONI, I. Resposta do milho a modos de aplicação de adubos e técnicas de preparo do solo. Revista Brasileira de Ciência do Solo, v.16, p.55-59, 1992. 
NACIF, A.P.; ALVES, J.D.; ALVAREZ, V.H.; MATOS, A.T. Localização de fósforo no solo: efeito no crescimento de plantas de milho. (compact disc). In: CONGRESSO LATINO AMERICANO DE CIÊNCIA DO SOLO, 13., Águas de Lindóia, 1996. Resumos expandidos. Campinas: SBCS, 1996.

NOVAIS, R.F.; FERREIRA, R.P.; NEVES, J.C.L.; BARROS, N.F. Absorção de fósforo e crescimento do milho com sistema radicular parcialmente exposto a fonte de fósforo. Pesquisa Agropecuária Brasileira, v.20, p.749-754, 1985.

NOVAIS, R.F.; NEVES, J.C.L.; BARROS, N.F. Ensaio em ambiente controlado. In: OLIVEIRA, A.J. de; GARRIDO, W.E.; ARAUJO, J.D.; LOURENÇO, S. (Coord.) Métodos de pesquisa em fertilidade do solo. Brasília: EMBRAPA; Secretaria de Administração Estratégica, 1991. p.189-253.

RAIJ, B. van; QUAGGIO, J.A. Métodos de análise de solo para fins de fertilidade. Boletim Técnico do Instituto Agronômico, n.81, p.1-31, 1983.
SILVA, D.J.; ALVARENGA, R.C.; ALVAREZ, V., V.H.; SOARES, P.C. Localização de fósforo e de cálcio no solo e seus efeitos sobre o desenvolvimento inicial do milho. Revista Brasileira de Ciência do Solo, v.17, p.203-209, 1993.

STUKENHOLTZ, D.P.; OLSEN, R.J.; GOGAN, G.; OLSON, R.A. On the mechanism of phosphorus-zinc interaction in corn nutrition. Soil Science Society of America Proceedings, v.30, p.759-763, 1966.

TRANI, P.E.; TAVARES, M.; SIQUEIRA, W.J. Alho. In: RAIJ, B. van; CANTARELlA, H.; QUAGGIO, J.A.; FURLANI, A.M.C. (Ed.) Recomendações de adubação e calagem para o Estado de São Paulo. Campinas: Instituto Agronômico; Fundação IAC, 1996. p.170. (Boletim Técnico, 100)

Received January 24, 2003

Accepted June 16, 2004 